\title{
Acute Toxicity of Thallium to Daphnia magna and Ceriodaphnia dubia
}

\author{
T.-S. Lin, ${ }^{1}$ P. Meier, ${ }^{2}$ J. Nriagu ${ }^{2}$ \\ ${ }^{1}$ Department of Environmental Engineering and Health, Yuanpei University of \\ Science and Technology, 306 Yuan-Pei Street, Hsih-Chu City, 300, Taiwan \\ ${ }^{2}$ Department of Environmental Health Sciences, School of Public Health, University \\ of Michigan, Ann Arbor, Ml 48109, USA
}

Received: 15 September 2004/Accepted: 8 June 2005

Thallium in the environment has been attracting some attention recently because intoxication from thallium is very common and occurs worldwide ( $\mathrm{Li}$ and Aldis 1997; Malbrain et al 1997; Manzo and Sabbioni 1988; Zhou and Liu 1985), and there is an increased demand for its compounds by high-tech industries (Smith and Carson 1977). $\mathrm{Tl}$ is used as a catalyst in certain alloys, optical lens, jewelry, low temperature thermometers, semiconductors, dyes and pigments and scintillation counters (Smith and Carson 1977). The mammalian toxicity of thallium is comparable to that of mercury, but greater than those of cadmium, copper, lead, and zinc (Manzo and Sabbioni 1988; Wallwork et al. 1985; Zhou and Liu 1985; Zitko 1975; Zitko et al. 1975). Due to its toxicity, Tl is listed as a priority pollutant along with $\mathrm{Pb}, \mathrm{Cd}$ and $\mathrm{Hg}$ by the US Environmental Protection Agency (Keith and Telliard 1979). The concentrations of $\mathrm{T} 1$ in freshwaters range from 1 to $1350 \mathrm{ng} / \mathrm{L}$ (Axner et al. 1993; Cheam et al. 1995; Lukaszewski et al. 1996; Miyazaki and Tao 1991). Tl is also more abundant in the Great Lakes waters than $\mathrm{Cd}$ and $\mathrm{Hg}$ (Cheam et al. 1995; Lin and Nriagu 1999). Thus, its aquatic toxicity should be carefully evaluated in order to appropriately assess its potential impact on the aquatic environment. According to sparse reports on aquatic toxicity of this metal species, $\mathrm{Tl}$ is more toxic than $\mathrm{Ni}, \mathrm{Cu}$, or $\mathrm{Zn}$ but less toxic than $\mathrm{Cd}$ or $\mathrm{Hg}$ to Hyalella azteca on a water-concentration basis (Borgmann et al. 1998). Unlike bivalent metal toxicants, the primary ionic form of $\mathrm{Tl}$ in oxygenated water is monovalent, and its principal analogue is $\mathrm{K}$. Therefore $\mathrm{Tl}$ toxicity and uptake was known to be affected by $\mathrm{K}$ concentrations in water. Daphnids are very sensitive to a broad spectrum of toxicants and are distributed widely in the Northern Hemisphere, and therefore have been attractive test organisms also due to their short generation cycle and ease of culture and maintenance (Benfield and Buikema 1980). In this study, the acute toxicity of this metal was evaluated with two Daphnia species.

\section{MATERIALS AND METHODS}

The stock solution of thallium nitrate was prepared by diluting the $1000 \mathrm{ppm}$ thallium nitrate standard solution (Perkin-Elmer) with moderately hard water, and the $\mathrm{pH}$ was adjusted to approximately 8 with $0.1 \mathrm{~N} \mathrm{NaOH}$ solution. Then test solutions of a series of concentrations were generated. Moderately hard water was 
prepared in accordance with the U.S. EPA guidelines $(1993,1994)$. It was used for culture and the maintenance of test organisms as well as for dilution in preparation of exposure concentrations.

Daphnia magna and Ceriodaphnia dubia, cultured in the laboratory at the University of Michigan, were used for the acute toxicity assays. D. magna and C. dubia were maintained and fed daily in an incubator room at $20 \pm 1{ }^{\circ} \mathrm{C}$ and at $25 \pm 1{ }^{\circ} \mathrm{C}$, respectively. Newly hatched babies $<24$ hour old were harvested and used for testing. All other aspects of the culture and maintenance of test species were carried out following U.S. EPA guidelines (1993, 1994). For acute toxicity testing, detailed procedures delineated by U.S. EPA were followed. Water quality parameters such as $\mathrm{pH}$, temperature, dissolved oxygen and specific conductivity of the test solutions and the control were measured and logged. Acute reference toxicity tests with the same species were performed to assure similar sensitivities of each organism over this study. The concentration ranges for definitive toxicity tests were obtained by conducting preliminary 24 -hr toxicity testing.

Each test employed five different concentrations plus a control and each of concentrations had four replicates with five organisms. After 48 hours, the number of survivors was counted. The ToxStat (version 3.5) with the Probit procedure was used to estimate EC50 value.

\section{RESULTS AND DISCUSSION}

Table 1 shows the results of three acute toxicity tests with $D$. magna. On average, an EC50 value of $1.66 \mathrm{mg} / \mathrm{L}$ was obtained from these assays. AD-1 was conducted in broader concentration ranges so that it resulted in slightly lower estimates. However all three EC50 estimates appeared to correspond well with one another.

Table 1. Acute toxicity of thallium nitrate to Daphnia magna.

\begin{tabular}{lll}
\hline Test Number & EC50 $(48 \mathrm{hr}, \mathrm{mg} / \mathrm{L})$ & $95 \%$ Confidence Interval \\
\hline $\mathrm{AD}-1$ & 1.45 & $1.08-1.77$ \\
$\mathrm{AD}-2$ & 1.86 & $1.68-2.18$ \\
$\mathrm{AD}-3$ & 1.66 & $1.46-1.92$ \\
\hline
\end{tabular}

Table 2 summarizes toxicities of several metals to $D$. magna. According to the EC50 estimate we obtained from this study, thallium displayed greater toxicity than manganese, cobalt, nickel, arsenic, cadmium, tin, barium, and lead; however, thallium was less toxic to D. magna than chromium, copper, zinc, silver, mercury or lanthanum.

Two tests were conducted with $C$. dubia, and the results are shown in Table 3. $C$. dubia indicated greater susceptibility to thallium than $D$. magna by the factor of 2.5. The probability unit of mortality versus $\mathrm{Tl}$ concentration on the logarithmic scale and their predicted regression lines for $D$. magna and $C$. dubia are described 
in Figure 1. In addition, the observed mortality of D. magna and C. dubia after 48-hour exposure to $\mathrm{Tl}(\mathrm{I})$ are shown in Figure 2.

Table 2. Acute toxicity of heavy metals to Daphnia magna.

\begin{tabular}{|c|c|c|c|}
\hline & \multicolumn{2}{|c|}{$\mathrm{EC} 50(\mathrm{mg} / \mathrm{L})$} & \multirow[t]{2}{*}{ Reference } \\
\hline & $24 \mathrm{hr}$. & $48 \mathrm{hr}$. & \\
\hline $\mathrm{HgCl}_{2}$ & 0.0081 & 0.0052 & Khangorot and Ray 1989 \\
\hline $\mathrm{AgNO}_{3}$ & 0.023 & 0.01 & Khangorot and Ray 1989 \\
\hline $\mathrm{CuSO}_{4} \cdot 5 \mathrm{H}_{2} \mathrm{O}$ & 0.536 & 0.093 & Khangorot and Ray 1989 \\
\hline $\mathrm{ZnSO}_{4} \cdot 7 \mathrm{H}_{2} \mathrm{O}$ & 1.00 & 0.56 & Khangorot and Ray 1989 \\
\hline $\mathrm{CdCl}_{2} \bullet \mathrm{H}_{2} \mathrm{O}$ & 4.66 & 1.88 & Khangorot and Ray 1989 \\
\hline $\mathrm{CoCl}_{2} \cdot 6 \mathrm{H}_{2} \mathrm{O}$ & 2.61 & 1.49 & Khangorot and Ray 1989 \\
\hline $\mathrm{NiCl}_{2} \bullet 6 \mathrm{H}_{2} \mathrm{O}$ & 10.90 & 7.59 & Khangorot and Ray 1989 \\
\hline $\mathrm{MnCl}_{2}$ & 10.00 & 8.28 & Khangorot and Ray 1989 \\
\hline $\mathrm{SnCl}_{2} \cdot 2 \mathrm{H}_{2} \mathrm{O}$ & 38.00 & 21.56 & Khangorot and Ray 1989 \\
\hline $\mathrm{BaCl}_{2}$ & 52.82 & 32.00 & Khangorot and Ray 1989 \\
\hline $\mathrm{As}^{5+}$ & 51.88 & 44.46 & Fargasova 1993 \\
\hline $\mathrm{Pb}^{2+}$ & 8.317 & 3.73 & Fargasova 1993 \\
\hline $\mathrm{Cr}^{6+}$ & 1 & 0.364 & Fargasova 1993 \\
\hline $\mathrm{Hg}^{2+}$ & 0.054 & 0.0186 & Fargasova 1993 \\
\hline $\mathrm{CuSO}_{4}$ & & 0.073 & Aramabasic et al. 1995 \\
\hline $\mathrm{Pb}\left(\mathrm{NO}_{3}\right)_{2}$ & & 55.6 & Aramabasic et al. 1995 \\
\hline $\mathrm{ZnSO}_{4}$ & & 0.075 & Aramabasic et al. 1995 \\
\hline $\mathrm{La}$ & 0.485 & 0.0432 & Barry and Meehan 2000 \\
\hline
\end{tabular}

Table 3. Acute toxicity of thallium nitrate to Ceriodaphnia dubia.

\begin{tabular}{lll}
\hline Test Number & EC50 $(48 \mathrm{hr}, \mathrm{mg} / \mathrm{L})$ & $95 \%$ (Confidence Interval) \\
\hline $\mathrm{AC}-1$ & 0.649 & $0.593-0.832$ \\
$\mathrm{AC}-2$ & 0.672 & $0.618-0.711$ \\
\hline
\end{tabular}

The estimated average EC50s for D. magna and $C$. dubia are 1.66 and $0.66 \mathrm{mg} / \mathrm{L}$, respectively, which indicate that thallium(I) is very toxic to Daphnia species (Lundgren 1992; Nishiuchi 1974). The EC01s are also obtained with the probit model; they are 0.81 and $0.41 \mathrm{mg} / \mathrm{L}$ for $D$. magna and C. dubia, respectively. The ratios of EC01 to EC50 (EC01/EC50) for Daphnia magna and Ceriodaphnia dubia are 0.5 and 0.6 , respectively, which indicate the safety margin of $\mathrm{Tl}(\mathrm{I})$ is modest and should therefore be handled carefully.

The disparity between these two species demonstrates that the surface area-to-volume may be a critical factor influencing the toxicity of $\mathrm{Tl}(\mathrm{I})$ to 


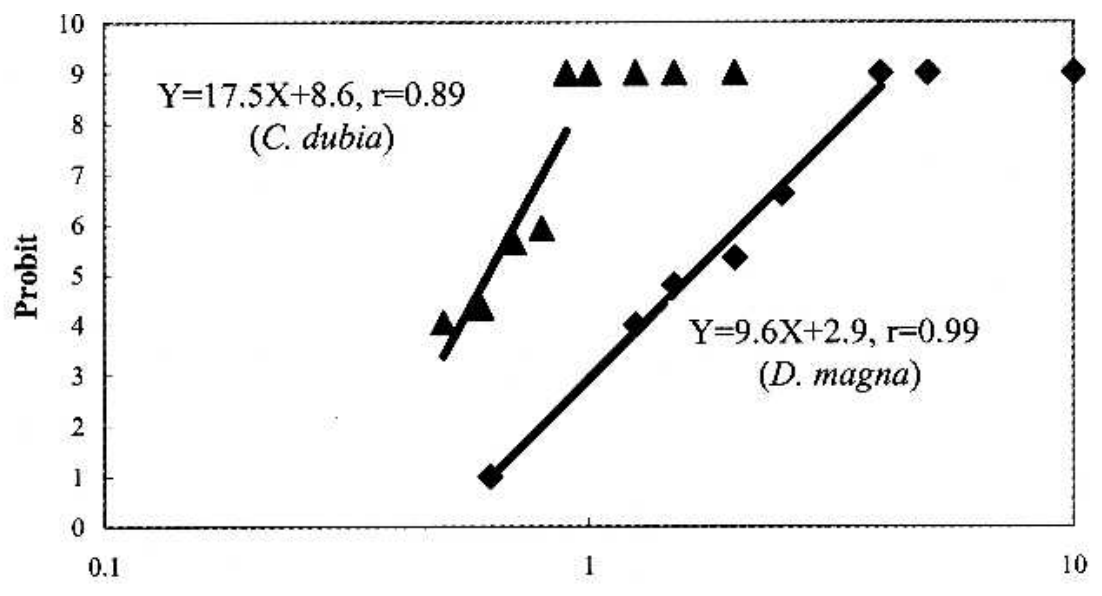

Concentration of $\mathrm{Tl}(\mathrm{I})(\mathrm{mg} / \mathrm{L})$

Figure 1. Probit versus Tl concentration on a logarithmic Scale for $D$. magna and C. dubia.

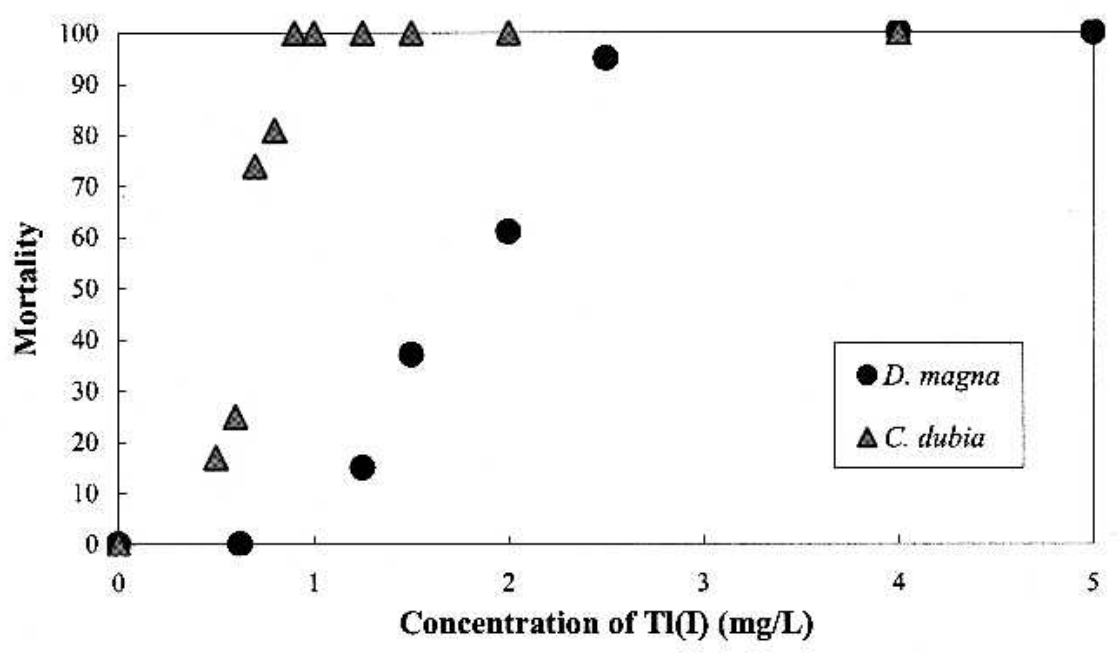

Figure 2. Mortality of Daphnia after 48 hour exposure to T1(I).

Daphnia species, since D. magna (2.6 $6 \mathrm{~mm}$ for female adult) is much larger than $C$. dubia $(0.3 \sim 0.6 \mathrm{~mm}$ for female adult). Because of its ionic radius (1.6 $\AA$ ) and the electronegativity constant (1.62), Tl(I) should behave like potassium, and to a lesser extent rubidium and silver, in aquatic ecosystems (Bodek et al 1988; Flegal et al 1989). Like the alkali metal analogues, $\mathrm{T} 1 \mathrm{OH}$ and $\mathrm{Tl}_{2} \mathrm{O}$ are readily soluble in water and $\mathrm{Tl}^{+}$forms relatively few strong complexes. However, the 
bioavailability of $T 1(\mathrm{I})$ may be depressed when $T 1(\mathrm{I})$ forms complexes and the observed toxicity could be less than expected in natural systems. Because the level of major ions in fresh waters is approximately $1 \times 10^{-4} \mathrm{M}, 10 \%$ of $\mathrm{Tl}(\mathrm{I})$ (assuming $[\mathrm{Tl}]<1 \times 10^{-5} \mathrm{M}$ ) can be expected in its complex forms if the stability constant is greater than $1 \times 10^{3}$; for instance, $\mathrm{TIPO}_{4}{ }^{2-}(\log \mathrm{K}=3.14), \mathrm{THCO}_{3}$ $(\log \mathrm{K}=3.42)$. On the other hand, monovalent thallium resembles silver in forming a very insoluble sulfide (solubility product for $\mathrm{Tl}_{2} \mathrm{~S}$ is $10^{-21.2}$ ) and sparingly soluble halide complexes that are light sensitive (Lin and Nriagu 1998). The $\mathrm{pH}$ of the aquatic environment also affects the chemical species of metals and thus their bioavailability. The proportion of $\mathrm{Tl}(\mathrm{OH})$ is only significant if the $\mathrm{pH}$ is greater than 9.5 (Lin and Nriagu 1998), and this does not usually happen in natural systems. Hardness is another important factor influencing the observed toxicity of metals, for example, copper (Borgmann et al 1998). However, hardness might only significantly affect the toxicity of bivalent cations; therefore, may not influence on the toxicity of $\mathrm{Tl}(\mathrm{I})$. This study clearly indicates that $\mathrm{Tl}(\mathrm{I})$ is very toxic to daphnids and the toxicity may not be abated by the hardness; thus may have potential to cause crucial deterioration of aquatic ecosystems.

\section{REFERENCES}

Arambasic MB, Bjelic S, Subakov G (1995) Acute toxicity of heavy metals (copper, lead, zinc), phenol and sodium on Allum cepa L., Lepidium sativum $L$. and Daphnia magna St: comparative investigations and the practical applications. Wat Res 29: 497-503.

Axner O, Chekalin N, Ljungberg, Malmsten Y (1993) Direct determination of thallium in natural waters by laser induced fluorescence in a graphite furnace. Anal Chem 53: 185-193.

Barry MJ, Meehan BJ (2000) The acute and chronic toxicity of lanthanum to Daphnia carinata. Chemosphere 41: 1669-1674.

Benfield EF, Buikema AL (1980) Synthesis of Miscellaneous Invertebrate Toxicity Test. In Buikema AL, Cairns J (ed) Aquatic Invertebrate Bioassays. STP 715. American Society for Testing and Materials, Philadelphia, PA, pp174-187.

Bodek I, Lyman WJ, Reehl WF, Rosenblatt DH (1988) Environmental Inorganic Chemistry, Pergamon Press. New York.

Borgmann U, Cheam V, Norwood WP, Lechner J. (1998) Toxicity and bioaccumulation of thallium in Hyalella azteca, with comparison to other metals and prediction of environmental impact. Environ Pollution 99:105-114.

Cheam V, Lechner J, Desrosiers R, Sekerka I, Lawson G, Mudroch A (1995) Dissolved and total thallium in Great Lakes waters. J Great Lakes Res 21:384-394.

Fargasova A (1994) Toxicity of metals on Daphnia magna and Tubifex tubifex. Ecotoxicol Environ Saf 27: 210-213.

Flegal AR, Sanudo-Wilhelmy S, Fitzwater SE (1989) Particulate Thallium Fluxes in the Northeast Pacific Ocean. Mar Chem 228: 61-75.

Keith LH, Telliard WA (1979) Priority Pollutants I - A perspective View Environ 
Sci Technol 13: 416-423.

Khangorot BS, Ray PK (1989) Investigation of correlation between physicochemical properties of metals and their toxicity to the water flea Daphnia magna Straus. Ecotoxicol Environ Safety 18:109-120.

Li, X, Aldis JW (1997) The First International Telemedicine Trial to China: Zhu Ling's case. http://www.radsci.ucla.edu/telemed.

Lin TS and Nriagu J (1999) Thallium speciation and distribution in the Great Lakes. Environ Sci Technol 33: 3394-3397.

Lin TS, Nriagu J (1998) Revised Hydrolysis Constants for Thallium(I) and Thallium(III) and the Environmental Implications. J Air Waste Manage 48:151-156.

Lukaszewski Z, Zembruski W, Oiela A (1996) Direct determination of ultratraces of thallium in water by flow-injection-differential-pulse anodic stripping voltammetry. Anal Chim Acta 318:159-165.

Lundgren A (1992) Environmental hazard classification of chemicals. Toxicol Lett. 64/65: 535-545.

Malbrain M, Lambrecht G, Zandijk D, Demedts E, Neels H, Lins R, Daelemans R (1985) Treatment of severe thallium intoxication. Clin Toxicol 35: 97-100.

Manzo L, Sabbioni E (1988) Thallium. In Seiler, HG, Sigel H (ed) Handbook on toxicity of inorganic compounds, Marcel Dekker Inc. New York. pp677-688.

Miyazaki A, Tao H (1991) Trace determination of thallium in water by laser enhanced ionization spectrometry using electrothermal vaporizer as a simple introduction system. Anal Sci 7:1053-1056.

Nishiuchi Y (1974) Testing methods for the toxicity of agricultural chemicals to aquatic organisms. Japan Pestic. 19: 15-19.

Smith IC, Carson BL (1977) Trace metals in the environment V(I). Ann Arbor Science, Ann Arbor.

U.S. EPA (1993) Methods for measuring the acute toxicity of effluents and receiving waters to freshwater and marine organisms, fourth edition (EPA/600/4-90/027F) Environmental Protection Agency. Washington D.C.

U.S. EPA (1994) Short-term methods for estimating the chronic toxicity of effluent and receiving water to freshwater organisms, third edition (EPA/600/4/91/ 002). Environmental Protection Agency. Washington D.C.

Wallwork-Barber M K, Lyall K, Ferenbaugh RW (1985) Thallium movement in a simple aquatic ecosystem. J Environ Sci Health A20: 701--720.

Zhou D, Liu D (1985) Chronic Thallium Poisoning in a Rural Area of Guizhou Province, China. J Environ Health 48:14-18.

Zitko V (1975) Toxicity and Pollution Potential of Thallium. Sci Tot Environ 4:185-192.

Zitko V, Carson WV, Carson WG (1975) Thallium: occurrence in the environment and toxicity to fish. Bull Environ Contam Toxicol 13: 23-30. 